Buletin Ilmiah Mat. Stat. dan Terapannya (Bimaster)

Volume 09, No. 4 (tahun), hal 489 - 496.

\title{
ALJABAR NONASOSIATIF DAN NONKOMUTATIF TERKAIT MUTASI
}

\author{
Paula, Yundari, Fransiskus Fran \\ INTISARI
}

Aljabar pada pewarisan genetik merupakan aljabar $\mathcal{A}$ atas $\mathbb{R}$. Aljabar $\mathcal{A}$ merupakan aljabar dengan realisasi genetik jika $\mathcal{A}$ memuat suatu segregasi Mendel. Hukum Mendel dalam pewarisan genetik menyatakan bahwa pada waktu pembentukan gamet tiap pasang gen disegregasi ke dalam masing-masing gamet yang terbentuk. Secara umum, dalam pewarisan genetik memungkinkan terjadinya suatu mutasi. Dalam penelitian ini dibahas tentang aljabar mutasi yang merupakan left almost algebra. Lebih lanjut dibahas pula tentang left almost algebra yang berkaitan dengan aljabar alternatif dan aljabar Jordan.

Kata Kunci : aljabar mutasi, aljabar alternatif, aljabar Jordan.

\section{PENDAHULUAN}

Genetika adalah cabang ilmu yang mempelajari tentang pewarisan sifat (hereditas) pada suatu organisme. Pewarisan sifat dapat terjadi ketika adanya suatu perkawinan pada organisme atau terjadi pembelahan sel pada organisme. Perkawinan acak dari makhluk hidup yang bersifat diploid (mempunyai sepasang kromosom) dan berbeda secara genetik dalam suatu populasi dapat terjadi kapan saja. Jika terjadi suatu pembuahan (bergabungnya sel sperma atau gamet jantan dengan sel telur atau gamet betina) maka akan terbentuk zigot. Di dalam satu gamet terdapat satu set kromosom sehingga gamet disebut sebagai sel haploid (hanya mempunyai satu kromosom). Kromosom merupakan struktur yang berisi asam deoksiribonukleat (DNA), asam ribonukleat (RNA), dan protein serta termasuk gen yang ada di dalamnya. Gen merupakan bagian dari kromosom yang berfungsi sebagai pembawa sifat. Suatu alternatif gen yang menjelaskan adanya variasi pada pewarisan suatu sifat disebut dengan alel (gen yang memiliki lokus yang sama) [1]. Alel terbentuk karena adanya variasi pada urutan basa nitrogen akibat peristiwa mutasi [2].

Mutasi adalah perubahan materi genetik yang dapat diturunkan dan memunculkan bentuk-bentuk alternatif gen lainnya. Terdapat dua macam mutasi yaitu mutasi gen dan mutasi kromosom (penyimpangan kromosomal). Mutasi kromosom yaitu mutasi yang disebabkan karena adanya perubahan jumlah kromosom, salah satunya mencakup duplikasi. Duplikasi terjadi jika terdapat satu atau lebih salinan segmen kromosom pada kromosom itu sendiri atau kromosom lain. Duplikasi dapat terjadi dalam peristiwa mutasi ketika dua untai DNA homolog saling tumpang tindih, lalu putus secara bersamaan di dua tempat yang berbeda (nonhomolog), kemudian menyambung kembali dengan untai yang salah [3].

Pada tahun 1980, Wörz-Busekros melakukan penelitian mengenai aljabar dalam genetika yang memberikan pembahasan tentang teori matematika aljabar dalam genetika serta membahas aplikasi pada genetik [4]. Beberapa penelitian lainnya juga telah membahas mengenai metode baru aljabar nonasosiatif dalam genetika [5].

Secara etimologi kata genetika berasal dari kata genos dalam bahasa Latin, yang berarti asal mula kejadian. Genetika yaitu ilmu tentang pewarisan sifat (hereditas) secara ilmiah dari generasi ke generasi. Sejarah perkembangan genetika sebagai ilmu pengetahuan dimulai menjelang akhir abad ke19 ketika seorang biarawan Austria bernama Gregor Johann Mendel berhasil melakukan analisis cermat dengan interpretasi yang tepat atas hasil-hasil percobaan persilangannya pada tanaman kacang 
ercis (Pisum sativum). Berbeda dengan para pendahulunya yang melihat setiap individu dengan keseluruhan sifatnya yang kompleks, Mendel mengamati pola pewarisan sifat demi sifat sehingga menjadi lebih mudah untuk diikuti. Hasilnya antara lain terjadi perubahan-perubahan pada warna, bentuk, ukuran dan sifat-sifat lain dari kacang polong tersebut. Selain itu ditemukan prinsip-prinsip pewarisan sifat, yang kemudian menjadi landasan utama bagi perkembangan genetika sebagai suatu cabang ilmu pengetahuan. Berkat karyanya inilah, Mendel diakui sebagai Bapak Genetika [6].

\section{STRUKTUR ALJABAR}

Matematika merupakan cabang ilmu pengetahuan yang digunakan untuk mengembangakan ilmuilmu lainnya. Matematika terdiri atas beberapa kelompok ilmu, seperti aljabar, analisis, statistika dan geometri. Ilmu yang mempelajari penyederhanaan serta pemecahan masalah menggunakan simbol yang menjadi pengganti konstanta atau variabel disebut aljabar. Bidang aljabar yang mempelajari aturan manipulasi rumus dan ekspresi yang melibatkan variabel bilangan real atau kompleks disebut aljabar elementer, sementara bagian aljabar yang mempelajari struktur aljabar adalah aljabar abstrak [7].

Suatu struktur aljabar merupakan suatu sistem yang mengandung dua unsur utama yakni sebuah himpunan dan operasi biner yang didefinisikan di dalamnya. Himpunan tak kosong $S$ dengan operasi biner $*$ disebut grupoid yang dituliskan dengan $(S, *)$. Grupoid $S$ dimana operasi biner berlaku sifat asosiatif, yaitu untuk setiap $a, b, c \in S$ berlaku $(a b) c=a(b c)$ disebut semigrup. Semigrup yang memiliki unsur identitas disebut monoid. Suatu grupoid $S$ merupakan left almost semigroup jika memenuhi hukum invertif kiri (left invertive law) yaitu $(a b) c=(c b) a$ untuk setiap $a, b, c, \in S$. Sebuah elemen identitas dari sebuah grupoid $S$ disebut identitas kiri (kanan) jika memenuhi ex = $x(x e=x)$ untuk semua $x$ di $S$. Jika grupoid $S$ merupakan left almost semigroup dengan identitas kiri $e$ untuk setiap $a, b, c \in S$ maka berlaku,

$$
a(b c)=b(a c) \text {. }
$$

Struktur lainnya ada yang disebut grup dan ada yang disebut ring. Sebuah ring komutatif dengan elemen satuan dan setiap elemen tak nol memiliki invers terhadap perkalian merupakan suatu field. Suatu struktur aljabar terkait field disebut ruang vektor yang didefinisikan sebagai berikut.

Definisi 1 [8] Sebuah himpunan V dikatakan ruang vektor atas field $\mathcal{F}$ jika $V$ suatu grup Abelian atas operasi penjumlahan dan untuk setiap $a \in \mathcal{F}$ dan $v \in V$, elemen av di $V$ serta kondisi berikut dipenuhi untuk setiap $a, b$ di $\mathcal{F}$ dan setiap $u, v$ di $V$, maka:

1. $a(v+u)=a v+a u$.

2. $(a+b) v=a v+b v$.

3. $a(b v)=(a b) v$.

4. $1 v=v$.

Setiap anggota field adalah skalar dan setiap anggota dari ruang vektor adalah vektor. Jadi perkalian antara skalar dan vektor disebut perkalian skalar.

Definisi 2 [8] Sebuah himpunan $S$ dari vektor-vektor dikatakan bergantung linear atas field $\mathcal{F}$ jika terdapat vektor-vektor $v_{1}, v_{2}, \ldots, v_{n}$ dari $S$ dan elemen $a_{1}, a_{2}, \ldots, a_{n}$ dari $\mathcal{F}$ sedemikian sehingga $a_{1} v_{1}+a_{2} v_{2}+\ldots+a_{n} v_{n}=0$ dengan nilai $a_{1}, a_{2}, \ldots, a_{n}$ tidak semuanya nol. Sebuah himpunan dari vektor-vektor tidak bergantung linear atas $\mathcal{F}$ disebut bebas linear atas $\mathcal{F}$. 
Contoh 3 Diberikan $S=\{(1,1),(-1,3)\} \subseteq \mathbb{R}^{2}$. Misalkan $k_{1}, k_{2} \in \mathbb{R}$ dan dibentuk kombinasi linear, maka diperoleh

$$
\begin{aligned}
k_{1}(1,1)+k_{2}(-1,3) & =(0,0) \\
\left(k_{1}-k_{2}, k_{1}+3 k_{2}\right) & =(0,0)
\end{aligned}
$$

Dari persamaan (2) dan (3) diperoleh bahwa $k_{1}=k_{2}=0$, yang berarti bahwa $S$ himpunan bebas linear atas $\mathbb{R}$.

Didefinisikan pula aljabar $\mathcal{A}$ atas field $\mathbb{R}, \mathcal{A}$ adalah sebuah ring sekaligus sebuah ruang vektor atas $\mathbb{R}$. Misalkan ada suatu aljabar Jordan $\mathcal{A}$ jika memenuhi definisi berikut.

Definisi 4 [9] Sebuah aljabar $\mathcal{A}$ atas field $\mathcal{F}$ dikatakan aljabar Jordan jika $\mathcal{A}$ bersifat komutatif dan memenuhi identitas Jordan.

$$
x^{2}(y x)=x\left(x^{2} y\right) \text { untuk semua } x, y \in \mathcal{A} .
$$

Dalam kondisi khusus suatu aljabar alternatif $\mathcal{A}$ tidak bersifat asosiatif jika memenuhi definisi berikut.

Definisi 5 [4] Suatu aljabar $\mathcal{A}$ dikatakan aljabar alternatif jika memenuhi identitas yang dikenal sebagai hukum alternatif kiri dan alternatif kanan untuk semua $x, y \in \mathcal{A}$

$$
\begin{array}{lll}
x^{2} y & =x(x y) & \text { alternatif kiri } \\
y x^{2} & =(y x) x & \text { alternatif kanan. }
\end{array}
$$

\section{ALJABAR DENGAN REALISASI GENETIK}

Jika terjadi suatu perkawinan acak antar individu, maka terjadi penggabungan gamet $a_{1}$ dan $a_{2}$ (dalam kasus ini $a_{1} a_{2}=a_{2} a_{1}$ ). Sehingga diperoleh zigot $a_{1} a_{1}, a_{1} a_{2}, a_{2} a_{1}$ dan $a_{2} a_{2}$ dimana $a_{1} a_{1}$ dan $a_{2} a_{2}$ dikenal sebagai homozigot (zigot dengan gen seragam) sementara $a_{1} a_{2}$ dan $a_{2} a_{1}$ disebut heterozigot (zigot dengan gen campuran). Berdasarkan hukum Mendel, dihasilkan persamaan $a_{1} a_{2}=\frac{1}{2}$ $\left(a_{1}+a_{2}\right)$ dengan $a_{1} a_{1}=a_{1}$ dan $a_{2} a_{2}=a_{2}$. Misalkan $\gamma_{i j k}$ merupakan peluang zigot $a_{i} a_{j}$ menghasilkan gamet baru $a_{k}$ dan gamet $a_{1}, a_{2}, \ldots, a_{n}$ merupakan elemen basis dari sebuah ruang vektor atas $\mathbb{R}$ yang berdimensi- $n$ dengan operasi perkalian yang didefinisikan sebagai berikut.

$$
a_{i} a_{j}=\sum_{k=1}^{n} \gamma_{i j k} a_{k}
$$

$$
\begin{aligned}
& \text { dengan } 0 \leq \gamma_{i j k} \leq 1, \quad i, j, k=1,2, \ldots, n \text {. } \\
& \sum_{k=1}^{n} \gamma_{i j k}=1, \quad i, j=1,2, \ldots, n \text {. } \\
& \gamma_{j i k}=\gamma_{i j k}, \quad i, j, k=1,2, \ldots, n .
\end{aligned}
$$

Suatu aljabar dengan basis $a_{1}, a_{2}, \ldots, a_{n}$ atas $\mathbb{R}$ dan memenuhi persamaan (4) disebut sebagai aljabar gamet, yang menjelaskan bahwa untuk setiap pasangan gamet $a_{i} a_{j}$ menghasilkan gamet $a_{k}$ dengan peluang $\gamma_{i j k}$ untuk $k=1,2, \ldots, n[10]$.

Untuk aljabar zigot, dimisalkan terdapat pasangan gamet $a_{i j}=a_{i} a_{j}$ dengan pengertian bahwa $a_{i j}=a_{j i}$ dengan $i<j$ untuk $i, j=1,2, \ldots, n$. Perkawinan acak dari zigot $a_{i j}$ dan $a_{p q}$ akan menghasilkan zigot $a_{k s}$ dengan peluang tertentu, dimisalkan sebagai $\gamma_{i j, p q, k s}$ dengan operasi perkalian didefinisikan sebagai berikut.

$$
a_{i j} a_{p q}=\sum_{k \leq s} \gamma_{i j, p q, k s} a_{k s}
$$

$$
\begin{gathered}
\text { dengan } 0 \leq \gamma_{i j, p q, k s} \leq 1 \\
\sum_{k, s=1}^{n} \gamma_{i j, p q, k s}=1 \\
\gamma_{i j, p q, k s}=\gamma_{p q, i j, k s},
\end{gathered}
$$


dimana $i \leq j, p \leq q$ dan $k \leq s$ untuk $i, j=1,2, \ldots, n$. Persamaan (5) menjelaskan bahwa setiap pasangan zigot $a_{i j}$ dan $a_{p q}$ ketika perkawinan acak $a_{i j} a_{p q}$ akan menghasilkan zigot baru yaitu $a_{k s}$ dengan peluang $\gamma_{i j, p q, k s}$ untuk $k \leq s$. Sebuah aljabar yang memenuhi perkalian dari persamaan (5) disebut sebagai aljabar zigot [10].

Aljabar pada pewarisan genetik merupakan aljabar $\mathcal{A}$ atas field $\mathbb{R}$. Secara umum, aljabar dengan realisasi genetik bersifat komutatif tetapi bersifat nonasosiatif. Jika individu $P$ dikawinkan dengan $Q$ dan hasilnya dikawinkan dengan individu $R$, hasil dari perkawinannya tidak akan sama dengan individu $P$ dikawinkan dengan hasil perkawinan $Q$ dengan $R$, atau dengan kata lain $(P \times Q) \times R \neq$ $P \times(Q \times R)$. Sedangkan jika individu $P$ dikawinkan dengan individu $Q$ hasilnya akan sama dengan individu $Q$ dikawinkan dengan $P$ atau $P \times Q=Q \times P$. Aljabar $\mathcal{A}$ merupakan aljabar dengan realisasi genetik jika $\mathcal{A}$ memuat suatu segregasi [1].

Suatu aljabar dengan realisasi genetik merupakan aljabar $\mathcal{A}$ atas $\mathbb{R}$ yang memilki basis $\left\{a_{1}, \ldots, a_{n}\right\}$ dan segregasi $\gamma_{i j k}$ sehingga

$$
a_{i} a_{j}=\sum_{k=1}^{n} \gamma_{i j k} a_{k} ; i, j=1,2, \ldots, n .
$$

Aljabar $\mathcal{A}$ disebut aljabar dengan realisasi genetik jika skalar $\gamma_{i j k}$ memenuhi:

$$
\begin{aligned}
& \text { dengan } 0 \leq \gamma_{i j k} \leq 1, \quad i, j, k=1,2, \ldots, n \text {. } \\
& \sum_{k=1}^{n} \gamma_{i j k}=1, \quad i, j=1,2, \ldots, n .
\end{aligned}
$$

Aljabar $\mathcal{A}$ dengan realisasi genetik atas $\mathbb{R}$ dan $p$ merupakan suatu populasi dapat dituliskan dalam kombinasi linear dengan basis $\left\{a_{1}, \ldots, a_{n}\right\}$ sebagai berikut.

$$
p=\alpha_{1} a_{1}+\alpha_{2} a_{2}+\cdots+\alpha_{n} a_{n} ; \quad p=\sum_{i=1}^{n} \alpha_{i} a_{i},
$$

maka $\alpha_{i}$ merupakan presentase dari populasi $p$ yang memuat alel $a_{i}$ dengan peluang $0 \leq \alpha_{i} \leq 1, i=$ $1,2, \ldots, n$ dan $\sum_{i=1}^{n} \alpha_{i}=1[10]$.

\section{ALJABAR MUTASI}

Mutasi adalah perubahan materi genetik (gen atau kromosom) suatu sel yang diwariskan kepada keturunannya. Mutasi dapat disebabkan oleh kesalahan replikasi materi genetika selama pembelahan sel oleh radiasi, bahan kimia (mutagen) atau virus. Mutasi juga terjadi karena adanya perubahan lingkungan. Tujuan mutasi adalah menghadapi perubahan alam yang sewaktu akan timbul. Ada dua kemungkinan yang dapat timbul yaitu sifat yang bermutasi lebih mudah beradaptasi dibandingkan dengan sifat yang asli dan sifat yang bermutasi tidak cocok terhadap lingkungan yang baru sehingga individu atau populasi suatu spesies akan punah [2].

Diberikan konsep aljabar mutasi berdasarkan aljabar gamet yang diperkenalkan oleh Gonshor (1960). Misalkan aljabar gamet memiliki basis dengan elemen $D$ dan $R$ serta tingkat mutasi $r$ dan $s$ untuk semua $r, s \in[0,1]$ dan didefinisikan operasi perkalian sebagai berikut

$$
\left.\begin{array}{l}
D^{2}=(1-r) D+r R \\
R^{2}=s D+(1-s) R
\end{array}\right\} \begin{aligned}
& D R=\frac{1}{2}(1-r+s) D+\frac{1}{2}(1-s+r) R
\end{aligned}
$$

Aljabar gamet dengan operasi perkalian tersebut disebut sebagai aljabar mutasi. Ketika $r=s=0$ tidak ada mutasi) artinya jika suatu makhluk hidup yang mengalami mutasi maka sudah stabil pada generasi kedua. Distribusi gen mendekati distribusi yang stabil ketika $r=s=1$. Tetapi pada kasus yang diperkenalkan oleh Gonshor, mutasi tidak stabil karena gamet memiliki basis $D$ dan $R$ akan menghasilkan zigot yaitu $D^{2}=R$ dan $R^{2}=D[11]$.

Anis dkk (2017) memperkenalkan konsep dari aljabar terkait mutasi yaitu misalkan aljabar $\mathcal{A}$ atas field $\mathcal{F}$ dengan operasi biner $(*)$ didefinisikan sebagai $a_{i} * a_{j}=\alpha a_{i}+\alpha^{2} a_{j},\left(\alpha+\alpha^{2}=1\right)$ untuk 
setiap $a_{i}, a_{j} \in \mathcal{A}$. Berdasarkan operasi biner tersebut, aljabar mutasi memenuhi persamaan (7) tetapi untuk $a_{i} * a_{i}=a_{i},\left\{a_{i}: 1 \leq i \leq n\right\}$. Ada beberapa kesamaan antara konsep-konsep aljabar mutasi yang diperkenalkan oleh [11] dan [12]. Aljabar mutasi ini dinotasikan $\mathcal{M}_{n}\left(\alpha_{\mathcal{F}}\right)$ yaitu suatu aljabar mutasi berdimensi- $n$ atas field $\mathcal{F}$.

Teorema 6 [12] $\mathcal{M}_{n}\left(\alpha_{\mathcal{F}}\right)$ adalah left almost algebra yang nonkomutatif dan nonasosiatif.

Bukti: Jelas $\mathcal{M}_{n}\left(\alpha_{\mathcal{F}}\right)$ tertutup. Misalkan $X, Y, Z \in \mathcal{M}_{n}\left(\alpha_{\mathcal{F}}\right)$ maka $X=\sum_{j=1}^{n} \beta_{j} a_{j}, Y=\sum_{k=1}^{n} \gamma_{k} a_{k}$ dan $Z=\sum_{l=1}^{n} \delta_{l} a_{l}$.

Akan ditunjukkan $(X * Y) * Z=(Z * Y) * X$.

$$
\begin{aligned}
(X * Y) * Z & =\left(\sum_{j=1}^{n} \beta_{j} a_{j} * \sum_{k=1}^{n} \gamma_{k} a_{k}\right) * \sum_{l=1}^{n} \delta_{l} a_{l} \\
& =\left(\sum_{j=1}^{n} \sum_{k=1}^{n} \beta_{j} \gamma_{k}\left(a_{j} * a_{k}\right)\right) * \sum_{l=1}^{n} \delta_{l} a_{l} \\
& \left.=\sum_{j=1}^{n} \sum_{k=1}^{n} \sum_{l=1}^{n} \beta_{j} \gamma_{k} \delta_{l}\left(a_{j} * a_{k}\right) * a_{l}\right)
\end{aligned}
$$

Disisi lain diperoleh

$$
\begin{aligned}
(Z * Y) * X & =\left(\sum_{l=1}^{n} \delta_{l} a_{l} * \sum_{k=1}^{n} \gamma_{k} a_{k}\right) * \sum_{j=1}^{n} \beta_{j} a_{j} \\
& =\left(\sum_{l=1}^{n} \sum_{k=1}^{n} \delta_{l} \gamma_{k}\left(a_{l} * a_{k}\right)\right) * \sum_{j=1}^{n} \beta_{j} a_{j} \\
& \left.=\sum_{l=1}^{n} \sum_{k=1}^{n} \sum_{l=1}^{n} \delta_{l} \gamma_{k} \beta_{j}\left(a_{l} * a_{k}\right) * a_{j}\right)
\end{aligned}
$$

Berdasarkan penjabaran di atas diperoleh $\left(a_{j} * a_{k}\right) * a_{l}=\left(a_{l} * a_{k}\right) * a_{j}$.

$$
\begin{aligned}
\left(a_{j} * a_{k}\right) * a_{l} & =\alpha\left(\alpha a_{j}+\alpha^{2} a_{k}\right)+\alpha^{2} a_{l} \\
& =\alpha^{2} a_{j}+\alpha^{3} a_{k}+\alpha^{2} a_{l}
\end{aligned}
$$

Disisi lain diperoleh

$$
\begin{aligned}
\left(a_{l} * a_{k}\right) * a_{j} & =\alpha\left(\alpha a_{l}+\alpha^{2} a_{k}\right)+\alpha^{2} a_{j} \\
& =\alpha^{2} a_{l}+\alpha^{3} a_{k}+\alpha^{2} a_{j} \\
& =\alpha^{2} x+\alpha^{3} y+\alpha^{2} z
\end{aligned}
$$

Berdasarkan persamaan (8) dan (9) diperoleh bahwa $(X * Y) * Z=(Z * Y) * X$.

Selanjutnya akan dibuktikan $X *(Y * Z) \neq(X * Y) * Z$ (bersifat nonasosiatif).

$$
\begin{aligned}
a_{j} *\left(a_{k} * a_{l}\right) & =\alpha a_{j}+\alpha^{2}\left(\alpha a_{k}+\alpha^{2} a_{l}\right) \\
& =\alpha a_{j}+\alpha^{3} a_{k}+\alpha^{4} a_{l}
\end{aligned}
$$

Dari persamaan (8) dan (10) diperoleh bahwa $X *(Y * Z) \neq(X * Y) * Z$.

Selanjutnya akan dibuktikan $X Y \neq Y X$ (bersifat nonkomutatif).

Diperoleh bahwa $a_{j} * a_{k}=\alpha a_{j}+\alpha^{2} a_{k}$ dan $a_{k} * a_{j}=\alpha a_{k}+\alpha^{2} a_{j}$ sehingga $X Y \neq Y X$ (bersifat nonkomutatif) untuk $X, Y \in \mathcal{M}_{n}\left(\alpha_{\mathcal{F}}\right)$.

Selanjutnya dibahas beberapa aljabar nonasosiatif lainnya yang berkaitan dengan left almost algebra. Sebuah aljabar alternatif $\mathcal{A}$ adalah sebuah aljabar nonasosiatif jika memenuhi sifat alternatif kiri dan alternatif kanan untuk setiap $x, y \in \mathcal{A}$ maka,

$$
\begin{array}{lll}
x(x y) & =(x x) y & \text { alternatif kiri } \\
(y x) x & =y(x x) & \text { alternatif kanan. }
\end{array}
$$


Lemma 7 [12] Jika $\mathcal{A}$ adalah left almost alternative algebra maka $x(x y)=(x x) y=(y x) x=y(x x)$ dan $x^{2} y=y x^{2}$ untuk semua $x, y \in \mathcal{A}$.

Bukti: Misalkan $x$ dan $y \in \mathcal{A}$ maka diperoleh

$$
\begin{aligned}
& x(x y)=(x x) y \quad \text { (alternatif kiri) } \\
& =(y x) x \quad \text { invertif kiri) } \\
& =y(x x) \quad \text { (alternatif kanan) }
\end{aligned}
$$

Karena $x(x y)=y(x x)$ memenuhi sifat alternatif kiri (kanan) sehingga berlaku $x^{2} y=y x^{2}$ untuk semua $x, y \in \mathcal{A}$

Berdasarkan Lemma 7, akibatnya diperoleh $x^{2} x=x x^{2}$ untuk $x \in \mathcal{A}$.

Lemma 8 [12] Jika $\mathcal{A}$ adalah sebuah left almost alternative algebra yang memuat identitas kiri e, maka $\mathcal{A}$ memenuhi sifat komutatif dan asosiatif dengan identitas.

Bukti:

Dari $x^{2} y=y x^{2}$, untuk semua $x$ dan $y$. Maka $x=e x=e^{2} x=x e^{2}=x e$. Sehingga diperoleh

$$
\begin{aligned}
x y & =(x y) e & & \text { (identitas kanan) } \\
& =(e y) x & & \text { (invertif kiri) } \\
& =y x & &
\end{aligned}
$$

Selanjutnya akan ditunjukkan bersifat asosiatif terhadap identitas untuk setiap $x, y, z \in \mathcal{A}$.

$$
\begin{aligned}
& (x y) z=(z y) x \quad \text { (invertif kiri) } \\
& =(y z) x \quad(\text { Lemma 7) } \\
& =a x \\
& =x a \\
& =x(y z)
\end{aligned}
$$

Terbukti bahwa left almost alternative komutatif dan asosiatif terhadap hukum invertif kiri.

Untuk pembahasan selanjutnya, diasumsikan $\mathcal{A}$ merupakan left almost alternative algebra yang memenuhi persamaan (1).

Lemma 9 [12] Jika $\mathcal{A}$ adalah left almost alternative algebra maka $y x^{n}=x^{n} y$ untuk semua $x, y \in$ $\mathcal{A}$ dan untuk $n \geq 2$.

Bukti:

Berdasarkan Lemma 7 diperoleh $x^{2} y=y x^{2}$ untuk semua $x, y \in \mathcal{A}$ akibatnya

$$
\begin{aligned}
& \left(x^{2} y\right) x=(x y) x^{2} \quad \text { (invertif kiri) } \\
& =y\left(x^{2} x\right) \quad(\text { pers } 7) \\
& =y x^{3}
\end{aligned}
$$

disisi lain diperoleh

$$
\begin{aligned}
\left(y x^{2}\right) x & =\left(x x^{2}\right) y \quad \text { (invertif kiri) } \\
& =x^{3} y
\end{aligned}
$$

Jadi $y x^{3}=x^{3} y$. Kemudian asumsikan bahwa $y x^{k}=x^{k} y$ untuk $k \geq 3$.

Maka diperoleh

$$
\begin{array}{rlrl}
\left(x^{k} y\right) x & =(x y) x^{k} & & \text { (invertif } \\
& & \text { kiri) } \\
& =y\left(x^{k} x\right) & & (\text { pers } 7) \\
& =y x^{k+1} &
\end{array}
$$

disisi lain diperoleh

$$
\left(y x^{k}\right) x=\left(x x^{k}\right) y \quad \text { (invertif kiri) }
$$


Jadi terbukti bahwa $y x^{n}=x^{n} y$ untuk $n \geq 2$

$$
\begin{aligned}
& =\left(x^{k} x\right) y \quad(\operatorname{Lemma} 7) \\
& =x^{k+1} y
\end{aligned}
$$

Selain left almost alternative algebra, Lemma 7 juga memenuhi aljabar Jordan.

Teorema 10 [12] Setiap $\mathcal{A}$ merupakan suatu aljabar Jordan

Bukti: Misalkan $x, y \in \mathcal{A}$ maka

$$
\begin{aligned}
& (x y) x^{2}=x^{2}(y x) \quad(\text { Lemma } 7) \\
& =y\left(x^{2} x\right) \quad(\text { pers } 7) \\
& =y\left(x x^{2}\right) \quad \text { (Lemma 7) } \\
& =x\left(y x^{2}\right)
\end{aligned}
$$

Jadi terbukti bahwa $(x y) x^{2}=x\left(y x^{2}\right)$ merupakan aljabar Jordan

Lemma 11 [12] Jika $\mathcal{A}$ adalah left almost alternative algebra maka $\left(x^{2} y\right) x=x^{2}(y x)$ untuk semua $x, y \in \mathcal{A}$

Bukti: Dengan $x^{2} y=y x^{2}$. Maka diperoleh

$$
\begin{aligned}
& \left(x^{2} y\right) x=(x y) x^{2} \quad \text { (invertif kiri) } \\
& =x^{2}(x y) \quad(\text { pers } 7) \\
& =(y x) x^{2} \quad(\text { Lemma 7) } \\
& =x^{2}(y x)
\end{aligned}
$$

Maka terbukti bahwa $\left(x^{2} y\right) x=x^{2}(y x)$

Lebih lanjut dibahas mengenai pangkat suatu elemen untuk menentukan generasi penerus (pangkat ke- $n$ ) dari generasi sebelumnya dalam suatu populasi. Didefinikan suatu $x \in \mathcal{A}$ dengan $x^{1}=x$ dan $x^{n+1}=x^{n} x$ untuk $n$ bilangan bulat positif.

Proposisi 12 [12] Aljabar $\mathcal{A}$ merupakan associative power.

Bukti: Diketahui bahwa $x \in \mathcal{A}$ dikatakan associative powers jika berlaku $x^{i} x^{j}=x^{i+j}$ untuk semua $i, j \in \mathbb{N}$

Akan dibuktikan bahwa $\mathcal{A}$ associative power

$$
\begin{aligned}
x^{i} x^{j} & =\underbrace{x x x \ldots x}_{i} \underbrace{x x x \ldots x}_{j} \\
& =\underbrace{x x x \ldots x}_{i+j} \\
& =x^{i+j}
\end{aligned}
$$

Jadi terbukti bahwa $\mathcal{A}$ merupakan associative power

Teorema 13 [12] Jika $\mathcal{A}$ merupakan associative power maka $\left(x^{n} x^{m}\right) y=y\left(x^{m} x^{n}\right)$ untuk $m>$ $2, n>1$.

Bukti: Misalkan $x, y \in \mathcal{A}$ maka

$$
\begin{aligned}
& \left(x^{n} x^{m}\right) y=\left(x^{m} x^{n}\right) y \quad \text { (Lemma 7) } \\
& =\left(y x^{n}\right) x^{m} \quad \text { (invertif kiri) } \\
& =x^{m}\left(y x^{n}\right) \quad \text { (Lemma 7) } \\
& =y\left(x^{m} x^{n}\right)
\end{aligned}
$$

Teorema 14 [12] Setiap $\mathcal{A}$ memenuhi identitas Jordan $\left(x^{m} y\right) x^{n}=x^{m}\left(y x^{n}\right)$ untuk $m \geq 1, n \geq 2$

Bukti: Dengan menggunakan induksi, untuk $m=1$ dan $n=1$ berlaku hal yang sama dari Teorema 13 maka diperoleh:

$$
\begin{aligned}
\left(x^{m} y\right) x^{n} & =\left(y x^{m}\right) x^{n} & & \text { pers 7) } \\
& =\left(x^{n} x^{m}\right) y & & \text { (invertif } \\
& & & \text { kiri) } \\
& =y\left(x^{m} x^{n}\right) & & \text { (Teorema }
\end{aligned}
$$




$$
=x^{m}\left(y x^{n}\right)
$$

\section{KESIMPULAN}

Berdasarkan penelitian diperoleh beberapa variasi aljabar, diantaranya aljabar gamet dan aljabar zigot. Aljabar gamet dan aljabar zigot digunakan untuk mengkaji suatu peluang pewarisan sifat pada suatu organisme. Aljabar pada pewarisan genetik merupakan aljabar $\mathcal{A}$ atas $\mathbb{R}$ yang bersifat komutatif dan bersifat nonasosiatif. Aljabar mutasi yang diperkenalkan oleh Anis dkk (2017) merupakan suatu left almost algebra yang nonkomutatif dan nonasosiatif. Salah satu aljabar nonasosiatif adalah aljabar alternatif. Aljabar alternatif yang memenuhi sifat invertif kiri disebut left almost alternative algebra. Suatu left almost alternative algebra dengan identitas kiri $e$ memenuhi sifat komutatif dan asosiatif. Left almost alternative algebra yang memenuhi sifat tertentu dapat memenuhi aljabar Jordan.

\section{DAFTAR PUSTAKA}

[1] Kurniawati, F.R. dan Lukito, A. Struktur Aljabar pada Pewarisan Genetik, MATHunesa, 2014, 3; 59-63.

[2] Warmadewi, D.A. Mutasi Genetik, Buku Ajar, Denpasar. 2017.

[3] Stansfield, W.D.; Colomé, J.S.; \& Cano, R.J. Schaum's Easy Outlines Molecular and Cell Biology, Erlangga, Jakarta. 2006.

[4] Wörz-Busekros, A. Algebras in Genetics, Lecture Notes in Biomathematics, New York, 1980; 34.

[5] Etherington, I.M.H. Genetic algebras, Proceedings of the Royal of Edinburgh, 1939; 59: 242258.

[6] Susanto, A.H. Genetika, Graha Ilmu, Yogyakarta. 2011.

[7] Nugroho, D.; Veronica R.B.; \& Mashuri. Struktur dan Sifat-sifat K-aljabar, UNNES Journal of Mathematics, 2017; 6: 82-91.

[8] Gallian, J.A. Contemporary Abstract Algebra, Edisi kesembilan, Cengage Learning, Boston. 2015.

[9] Albert, A.A. A Structure Theory For Jordan Algebra, Annals of Mathematics, 1946; 48: 3.

[10] Reed, M.L. Algebraic Structure of Genetic Inheritance, American Mathematical Society, 1997; 34: 107-130.

[11] Gonshor, H. Special Train Algebras Arising in Genetics, Proceedings of the Edinburgh Mathematical Society, 1960; 12: 41-53.

[12] Anis, S.; Khan, M.; \& Khan, S. Mathematical Modeling for Inherited Diseases, Computational and Mathematical Methods in Medicine, 2017; 1-6.

PAULA $\quad$ : Jurusan Matematika FMIPA UNTAN, Pontianak paulapriyonaa@gmail.com

YUNDARI : Jurusan Matematika FMIPA UNTAN, Pontianak yundari@math.untan.ac.id

FRANSISKUS FRAN : Jurusan Matematika FMIPA UNTAN, Pontianak fransiskusfran@math.untan.ac.id 